\title{
Organizuotas nusikalstamumas: nauji iššūkiai ir atsakas i juos
}

\begin{abstract}
Organizuotas nusikalstamumas politiniu lygmeniu seniai traktuojamas kaip grèsmè nacionaliniam saugumui. Tačiau realus šio pavojaus aktualumas lieka neaiškus. Kodèl ši problema „saugumizuojama“? Ar apskritai ją derètų ịtraukti ị svarbiausių grèsmių sąrašą? Galbūt šį reiškinį reikètų priimti kaip tipinę problemą, kuri būtų sprendžiama ịprastomis priemonèmis? Straipsnyje ieškoma atsakymų i šiuos klausimus. Organizuotas nusikalstamumas nagrinëjamas lyginant Lietuvos ir Europos Sąjungos perspektyvas. Siekiama ịvertinti jo poveikį ekonomikai ir visuomenés vertybėms. Darbe analizuojami nacionaliniai ir Europos Sąjungos strateginiai dokumentai, ịvardijantys organizuoto nusikalstamumo keliančias grèsmes, vertinamos nusikalstamos grupuotės, jų veiklos sritys, poveikis visuomenės saugumui, veiksniai, lemiantys organizuoto nusikalstamumo vystymosi ypatumus, atskleidžiamos organizuoto nusikalstamumo sąsajos su kitomis grèsmèmis. Straipsnyje taikomi sisteminio vertinimo, lyginamasis, dokumentų ir teisminès praktikos analizės metodai. Straipsnyje taip pat pateikiama interviu su valstybės tarnautojais ir operatyviniais darbuotojais metu gauta informacija.
\end{abstract}

\section{Ivadas}

Tarptautiniu lygmeniu apie organizuotą nusikalstamumą pradèta diskutuoti dar XIX a., tačiau Lietuvoje šią temą plačiau imta nagrinèti tik po nepriklausomybès atkūrimo. Organizuotas nusikalstamumas mūsų šalyje egzistavo ir sovietinès okupacijos laikotarpiu, bet tada šiuo klausimu buvo vengiama kalbèti, informacija disponavo tik jègos ir saugumo struktūros ${ }^{1}$. Po 1990 m. kovo 11 d. kriminologai, pareigūnai, žurnalistai pradèjo analizuoti faktinę nusikalstamumo padètị Lietuvoje. Organizuotas nusikalstamumas formaliuose Europos Sajungos, NATO ir nacionaliniuose dokumentuose ne kartą įvardytas kaip grèsmė nacionaliniam saugumui, tačiau moksliškai šis aspektas liko beveik nenagrinètas. Nors dar 2000 m. dr. Kęstutis Šimkus kèlè

\footnotetext{
Klaidas Kuchalskis - Lietuvos Respublikos vidaus reikalų ministerijos Viešojo saugumo ir migracijos politikos departamento direktorius. Adresas korespondencijai: Šventaragio g. 2, 01510 Vilnius; tel. 85271 7248; el. paštas: rkkuchalskiai@casema.nl.

" Šiame straipsnyje pateikiami autoriaus vertinimai, kurie jokiomis aplinkybèmis nèra oficiali Vidaus reikalu ministerijos pozicija.

${ }^{1}$ Sovietiniame LTSR baudžiamajame kodekse net nebuvo organizuotos grupès apibrěžimo. 
klausimą apie tarptautinio organizuoto nusikalstamumo bruožus, kurie sukelia didžiausią grèsmę nacionaliniam saugumui ${ }^{2}$, vèliau su šia tema susijusių akademinių darbų beveik nerandame. Šio straipsnio naujumas vertintinas per tyrimo objektą - veiksnius, darančius įtaką organizuoto nusikalstamumo keliamoms grèsmèms, bei priemones kuriant ir igyvendinant efektyvią kovos su šiuo reiškiniu politiką. Pagrindinis tyrimo uždavinys - atsižvelgiant ị šių dienų aktualijas, socialiniu, teisiniu ir politiniu požiūriu ịvertinti organizuoto nusikalstamumo poveikị visuomenès saugumui ir ekonomikai. Tyrimo metu analizuojant mokslinę literatūrą, Europos Sąjungos ir Lietuvos teisès aktus, taip pat remiantis ilgalaike autoriaus praktika kovos su tarptautiniu organizuotu nusikalstamumu srityje, buvo atsižvelgta ị ịvairiausius veiksnius, ịskaitant socialinius pokyčius, veikiančius organizuoto nusikalstamumo kaitą ir raidą.

Šiuolaikinès organizuotos nusikalstamos grupuotés veikia pagal legalaus verslo modelị, siekiantị planuojamų nuolatinių pajamų. Jų daroma žala daro itaką žmogiškiesiems, ekonominiams ir socialiniams veiksniams. Lietuvos Respublikos Konstitucinis teismas yra pažymèjęs, jog ,jeigu nebūtų užkertamas kelias organizuotam nusikalstamumui, jeigu organizuotos nusikalstamos grupès [...] nebūtų persekiojamos, iškiltų grèsmè konstitucinèms vertybėms, inter alia asmens teisėms ir laisvėms, Konstitucijoje įtvirtintiems visuomenès gyvenimo teisiniams pagrindams, valstybei, [...] visai visuomenei ${ }^{\text {“3. }}$. Operatyvinès tarnybos renka informaciją apie grupuočių narius ir jų veiklą, tačiau ne visuomet pavyksta šią medžiagą "paversti“ “ $\mathfrak{i}$ ikiteisminius tyrimus, grupuotes išskaidyti, jų narius nuteisti. Kai kurios šalys (Nyderlandai, Jungtinẻ Karalystė) sudaro vadinamuosius top-100 didžiausių nusikaltèlių sąrašus, skiria didelius išteklius jų veikų tyrimams, tačiau dažnai atsitinka, jog surinktos informacijos nepakanka, kad ịtariamieji būtų patraukti atsakomybèn. Kartais netgi pripažistama, kad jie yra nepažeidžiami. Stebint organizuotų nusikalstamų grupuočių daromą ịtaką îvairiose gyvenimo srityse, tokie faktai verčia sunerimti.

Straipsnị sudaro trys dalys. Pradžioje organizuotas nusikalstamumas analizuojamas per kylančias grèsmes Lietuvos nacionaliniam saugumui, vèliau jis vertinamas iš Europos Sąjungos perspektyvos, atskleidžiama grupuočių struktūra, veiklos sritys, evoliucija. Baigiamojoje dalyje apžvelgiamos organizuoto nusi-

\footnotetext{
${ }^{2}$ Šimkus K. (2000), „Organizuotas nusikalstamumas kaip grèsmè nacionaliniam saugumui“, Jurisprudencija 15 (7), p. 143-152.

${ }^{3}$ Lietuvos Respublikos Konstitucinis teismas (2004), Nutarimas dèl Lietuvos Respublikos organizuoto nusikalstamumo užkardymo ịstatymo 3 straipsnio (2001 m. birželio 26 d. redakcija), 4 straipsnio (2001 m. birželio 26 d., $2003 \mathrm{~m}$. balandžio 3 d. redakcijos), 6 straipsnio (2001 m. birželio 26 d. redakcija) 3 dalies ir 8 straipsnio (2001 m. birželio 26 d. redakcija) 1 dalies atitikties Lietuvos Respublikos Konstitucijai, http://www.lrkt.lt/lt/teismo-aktai/paieska/135/ta277/content, 2017-12-03.
} 
kalstamumo sąsajos su terorizmu ir kitomis grèsmèmis, susumuojamos įžvalgos, kodèl organizuotas nusikalstamumas negali būti traktuojamas kaip tipinis reiškinys ir šiai problemai spręsti būtinos nestandartinès priemonès.

\section{Grèsmès nacionaliniam saugumui}

Siekiant suprasti organizuoto nusikalstamumo kaip reiškinio mastą ir aktualumą, būtina išanalizuoti strateginius teisès aktus, ịvardijančius pačią problemą ir pateikiančius jos sprendimo būdus. Lietuvos Respublikos Seimas 2017 m. patvirtino naujos redakcijos Nacionalinio saugumo strategiją (toliau - Strategija). Joje - penkiolika grèsmių, pavojų ir rizikos veiksnių, kuriems „nacionalini saugumą užtikrinančios institucijos turi skirti ypatingą demesį “4. Viena jų - organizuotas nusikalstamumas: „šio reiškinio plitimas ir skverbimasis ị šalies ūkị ir finansų rinkas gali kelti rimtą pavojų visuomenès saugumui, neigiamai veikti

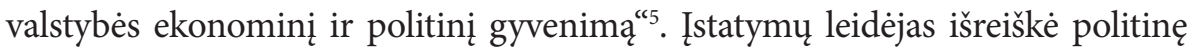
valią ir ịpareigojo atsakingas institucijas imtis neatidèliotinų veiksmų mažinant organizuoto nusikalstamumo keliamas grèsmes. Tai skatina organizuotą nusikalstamumą nagrinèti plačiau, kaip grèsmę nacionaliniam saugumui. Vis dèlto analizuojant Strategiją, pastebimi tam tikri neapibrèžtumai:

- Teigiama, kad organizuoto nusikalstamumo plitimas gali kelti rimtą pavojų saugumui. Preziumuotina, kad šiuo metu tokio pavojaus lyg ir nèra, nusikalstamumas neveikia valstybès ekonominio ir politinio gyvenimo.

- Organizuotas nusikalstamumas ịvardijamas kaip tryliktoji grèsmè. Neaišku, ar pavojai pateikti atsitiktine tvarka ar pagal svarbą, tačiau manytina, kad organizuotas nusikalstamumas nerra traktuojamas kaip ypač prioritetinis reiškinys.

- Ankstesnèje 2002 m. Strategijos redakcijoje organizuotas nusikalstamumas taip pat buvo ịvardytas kaip grésmé socialiniam stabilumui, neigiamai veikianti visuomenès saugumą ir ekonomikos plètrą ${ }^{6}$. Lyginant $2002 \mathrm{~m}$. ir 2017 m. Strategijas, stebimos beveik identiškos nuostatos dèl organizuoto nusikalstamumo, todèl darytina išvada, kad situacija per penkiolika metų nepasikeitè.

\footnotetext{
${ }^{4}$ Lietuvos Respublikos Seimas (2017), Nutarimas dèl Nacionalinio saugumo strategijos patvirtinimo, https://e-seimas.lrs.lt/portal/legalAct/lt/TAD/4c80a722e2fa11e6be918a531b2126ab?jfwid=-1fhjp2nto, 2017-11-26.

${ }^{5}$ Ten pat.

${ }^{6}$ Lietuvos Respublikos Seimas (2002), Nutarimas dèl Nacionalinio saugumo strategijos patvirtinimo, https://www.e-tar.lt/portal/legalAct.html?documentId=TAR.2627131DA3D2, 2017-11-26.
} 
Strategijoje pateikiama aštuoniolika nacionalinio saugumo politikos prioritetų ir uždavinių. Viešojo saugumo stiprinimas įvardytas kaip vienuoliktas prioritetas (vèlgi neaišku, ar prioritetai pateikiami svarbos ar atsitiktine tvarka):

Siekdama mažinti organizuoto nusikalstamumo [...] keliamas grèsmes [...], Lietuvos Respublika: [...] stiprins organizuoto nusikalstamumo prevenciją ir kontrolę, ypatingą dėmesi skirdama organizuotoms nusikalstamoms grupėms, turinčioms sąsajų su [...] teroristinemis organizacijomis [...]; užtikrins patikimą ES išorès sienos [...] apsaugą ir stiprins neteisètos migracijos prevenciją ir kontrolę [...]; plètos viešojo saugumo įstaigų pajègumus ir gebejimus [...], stiprindama šių ịstaigų veiklos koordinavimą ir [...] bendradarbiavimą bei didindama investicijas ị pažangias technologijas $[\ldots]^{7}$.

Analizuojant Strategiją moksliškai, reikia suvokti „strategijos“ termino apibrèžtị. Pirmąji šiuolaikinị strategijos apibrěžimą pateikė profesorius Alfredas Chandleris $1962 \mathrm{~m}$. Pasak jo, strategija apima tris pagrindinius elementus: ilgalaikius tikslus, veiklos kryptị ir reikiamus tikslo pasiekimo išteklius ${ }^{8}$. Strateginiame planavime svarbu apibrèžti konkrečius „norimus rezultatus, kurie turi būti pasiekti per nurodytą laikotarpi ${ }^{\text {“9 }}$. Strategijoje formuluojami ilgalaikiai saugios valstybės tikslai ir prioritetinès kryptys, tačiau apie šių tikslų pasiekimo būdus gana aptakiai užsimenama tik baigiamosiose nuostatose: „Strategijos nuostatos igyvendinamos per ilgalaikes valstybines saugumo stiprinimo programas. Lietuvos Respublikos Vyriausybè užtikrina, kad Strategijos [...] nuostatos būtų ịtrauktos ị kitus strateginio planavimo dokumentus "10. Siekiant igyvendinti vidaus saugumo politikos prioritetus, $2015 \mathrm{~m}$. Seimas patvirtino Viešojo saugumo plètros 2015-2025 metų programą ${ }^{11}$ (toliau - Programa), ilgalaiki valstybinio saugumo stiprinimo planą. Programoje numatytos konkrečios priemonès organizuotam nusikalstamumui mažinti, atkreipiamas dèmesys i tarpinstitucinio bendradarbiavimo svarbą, bendruomenių ìsitraukimą. Vienas iš Programos tikslų: „sukurti aplinką, nepalankią organizuotam nusikalstamumui [...] ir mažinti sunkių ir labai sunkių, taip pat organizuotų

\footnotetext{
${ }^{7}$ Lietuvos Respublikos Seimas (2017), Nutarimas dèl Nacionalinio saugumo strategijos patvirtinimo, https://e-seimas.lrs.lt/portal/legalAct/lt/TAD/4c80a722e2fa11 e6be918a531b2126ab?ffwid=-1fhjp2nto, 2017-11-26.

${ }^{8}$ Alfred D. Chandler (1962), Strategy and Structure: Chapters in the History of the Industrial Enterprise, Cambridge, Massachusetts: Massachusetts Institute of Technology, p. 13.

${ }^{9}$ Kuchalskis K., Gutauskas A. (2009), „Narkotikų prevencijos ir kontrolès politika Europos Sajungoje: nuo standartų paieškos link unifikavimo", Verslo ir teisés aktualijos (4), p. 122-139.

${ }^{10}$ Lietuvos Respublikos Seimas (2017), Nutarimas dèl Nacionalinio saugumo strategijos patvirtinimo, https://e-seimas.lrs.lt/portal/legalAct/lt/TAD/4c80a722e2fa1le6be918a531b2126ab?jfwid=-15zxvve2ep, 2017-12-31.

${ }^{11}$ Lietuvos Respublikos Seimas (2015), Nutarimas dèl Viešojo saugumo plètros 2015-2025 metu programos patvirtinimo, https://www.e-tar.lt/portal/lt/legalAct/ea944da0f95d11e4927fdald051299fb, 2017-12-31.
} 
nusikalstamų grupuočių daromų nusikaltimų žalą visuomenei“12. Tikslas aiškus, tačiau jam pasiekti numatomi uždaviniai nekonkretūs, neišmatuojami, deklaratyvaus pobūdžio, be realių igyvendinimo kriterijų:

Sukurti veiksmingas [...] sunkių nusikaltimų grèsmių vertinimo ir bendrų prioritetų nustatymo ir organizuoto nusikalstamumo kontrolès sistemas; [...] sukurti nepalankią aplinką nusikalstamoms veikoms [...]; plètoti teisėsaugos institucijų [...] bendradarbiavimą ir keitimąsi informacija [...]; didinti [...] pinigų plovimo prevencijos priemonių veiksmingumą; didinti nusikalstamu būdu gauto turto paieškos, areštavimo ir konfiskavimo mechanizmo veiksmingumą; [...] mažinti grèsmes, susijusias su neteisètu [...] tarptautinès finansinès paramos lèšu gavimu ir panaudojimu [...]; aktyviai bendradarbiauti su Europos kovos su elektroniniu nusikalstamumu centru [... $]^{13}$.

Sunku įvertinti, ko konkrečiai ir kaip norima pasiekti, kuriant „veiksmingas sistemas“ ir "nepalankią aplinką", „didinant veiksmingumą", „mažinant grèsmes“ ar „aktyviai bendradarbiaujant“. Numatytas tik vienas uždavinių igyvendinimo kriterijus - ištirtų sunkių ir labai sunkių nusikaltimų, numatytų atitinkamuose Lietuvos Respublikos baudžiamojo kodekso straipsniuose, procentualus didejjimas. SMART ${ }^{14}$ metodika, ko gero, buvo užmiršta. Prioritetinès priemonès taip pat igyvendinamos per septynioliktosios Lietuvos Respublikos Vyriausybès programą ${ }^{15}$. Nors joje tiesiogiai apie organizuotą nusikalstamumą beveik nekalbama, Vyriausybė ịsipareigoja prisidèti prie efektyvaus atsako $\mathfrak{i}$ tokius tarptautinius iššūkius kaip terorizmas, migracijos krizè, Europos Sajungos sienų apsaugos stiprinimas, yra numačiusi priemonių korupcijai mažinti.

Organizuoto nusikalstamumo neįmanoma nagrinèti atskirai nuo korupcijos. Transparency International duomenimis, $2016 \mathrm{~m}$. Lietuvos korupcijos suvokimo indeksas buvo 59 balai iš 100 galimų $^{16}$, t. y. Lietuva užèmè 38 vietą iš 176 valstybių sąrašo ${ }^{17}$. Tarp Europos Sąjungos valstybių narių Lietuva užima 16 vietą (sąraše pirmauja Danija su 90 balų) ${ }^{18}$. Pastaruoju metu organizuotas nusikalstamumas aktyviai veržiasi ị verslo sferą, stengiasi legalizuoti neteisètai igytas lèšas, investuoti ị nekilnojamajj turtą, statybų, transporto ir logistikos

\footnotetext{
12 Ten pat.

${ }^{13}$ Ten pat.

${ }^{14}$ SMART principas: keliami tikslai ir uždaviniai turi būti $S$ - Specific (konkretūs); $M$ - Measurable (išmatuojami); A - Assignable (priskirtini); R - Realistic (pasiekiami); T - Time-related (apriboti laiku). ${ }^{15}$ Lietuvos Respublikos Seimas (2016), Nutarimas dèl Lietuvos Respublikos Vyriausybès programos, https://e-seimas.lrs.lt/portal/legalAct/lt/TAD/886c7282c12811e682539852a4b72dd4?jfwid=-1fhjp2mhr, 2017-11-26.

${ }^{16}$ Korupcijos suvokimas šalyse ịvertinamas konkrečiu skaičiumi šimto balų skalëje nuo 0 iki 100, kurioje 0 reiškia, kad šalis yra labai korumpuota, 100 - kad labai skaidri.

${ }^{17}$ Transparency International (2017), Corruption Perceptions Index 2016, https://www.transparency.org/ news/feature/corruption_perceptions_index_2016, 2017-12-02.

${ }^{18}$ Specialiųjų tyrimų tarnyba (2017), Korupcijos suvokimo indeksas 2016 m.: Lietuvos situacijos apžvalga, https://www.stt.lt/lt/menu/tyrimai-ir-analizes/, 2017-12-02.
} 
verslą, taip pat siekia manipuliuoti Europos Sąungos struktūriniais fondais. Nusikalstamos grupuotès, naudodamos kyšininkavimo, interesų konflikto, itakos ir poveikio schemas, bando sukurti lengvesnes sąlygas nusikalstamoms veikoms vykdyti. Tokiu būdu iškraipoma teisèta konkurencija ir ardomas visuomenès pasitikejimas valstybès institucijomis ir valdymo sistema.

Aukščiausios valstybès institucijos ịvardija organizuotą nusikalstamumą kaip realią grèsmę nacionaliniam saugumui ir suteikia aiškų mandatą su šiuo reiškiniu kovojančioms tarnyboms. Iš Lietuvos Respublikos Vyriausybès tikimasi konkrečių rezultatų mažinant organizuoto nusikalstamumo ir korupcijos mastus. Norint ịgyvendinti šiuos ambicingus tikslus, būtinas visų susijusių institucijų bendradarbiavimas, veiksmų koordinacija, keitimasis informacija bei užtikrintas stabilus priemonių finansavimas. Siekiant veiksmingo atsako, pirmiausia būtina išanalizuoti esamą situaciją, suprasti organizuoto nusikalstamumo esmę ir vystymosi tendencijas, nustatyti pagrindines prioritetines kovos sritis. Šios temos plètojamos straipsnio antrojoje ir trečiojoje dalyse.

\section{Organizuoto nusikalstamumo vertinimas}

Lietuvos organizuoto nusikalstamumo neįmanoma vertinti atskirai nuo Europos Sąjungos situacijos. Tarptautinio organizuoto nusikalstamumo keliamos problemos yra aktualios globaliu mastu, todèl šalys privalo vienytis, kartu spręsti šiuos iššūkius. Europos Sąjungos valstybių narių ir šalių kandidačių paktas, priimtas 1998 m., organizuotą nusikalstamumą ịvardijo kaip kelianti didelę grèsmę demokratijai, žmogaus teisèms ir teisinei valstybei, „kadangi jis visuose lygmenyse ịsiskverbia ị valdžios struktūras, teisètas komercines ir finansinių paslaugų įmones bei visuomenę, jas užkrečia ir korumpuoja ${ }^{\text {"19 }}$. Nors nuo 2015 m. „saugumo situacijos Rytų Europoje klausimą ėmé gožti kova su terorizmu ir migracijos krize““20, šie klausimai Europos Sąungos ir NATO darbotvarkëje išlieka vieni svarbiausių. Europolas, Europos Sąjungos teisėsaugos agentūra, $2017 \mathrm{~m}$. atliko sunkių formų ir organizuoto nusikalstamumo grèsmių vertinimą (toliau - SOCTA, angl. Serious and Organised Crime Threat Assessment $t^{21}$ ), kuriame pateikè rekomendacijų dèl svarbiausių nusikalstamumo

\footnotetext{
${ }^{19}$ Europos Sajungos Teisingumo ir vidaus reikalų taryba (1998), Europos Sajungos valstybiu nariu ir Vidurio bei Rytu Europos šaliu kandidačiu ir Kipro paktas pasirengimo stojimui laikotarpiu dèl organizuoto nusikalstamumo, http://eur-lex.europa.eu/legal-content/LT/TXT/PDF/?uri=CELEX:41998D0715\&from= EN, 2018-01-21.

${ }^{20}$ Lietuvos Respublikos valstybès saugumo departamentas, Antrasis operatyvinių tarnybų departamentas prie Krašto apsaugos ministerijos (2016), Grèsmiu nacionaliniam saugumui vertinimas, Vilnius, p. 3.

${ }^{21}$ Europol (2017), SOCTA 2017, https://www.europol.europa.eu/socta/2017/, 2017-12-02.
} 
grèsmių, su kuriomis susiduria Europos Sąunga, rinkinị. SOCTA ataskaita grindžiamos valstybių narių diskusijos apie kovos su nusikalstamumo grèsmèmis prioritetus ${ }^{22}$. Ši analize parengta kaip kovos su organizuotu nusikalstamumo Europos Sąjungoje 2018-2021 metų politikos ciklo dalis ${ }^{23}$. Ciklo tikslas - remiantis faktiniais kriminalinès žvalgybos duomenimis ir tarpdiscipliniu požiūriu, nustatyti nusikalstamumo grèsmes, patvirtinti jas politiniu lygmeniu ir igyvendinti strateginius bei operatyvinius siekius. Ciklą sudaro keturi etapai:

1. Politikos plètojimas - SOCTA. Pateikiama grèsmių analizè, remiantis ja Europos Sąjungos Teisingumo ir vidaus reikalų ministrų taryba nustato kovos su organizuotu nusikalstamumu prioritetus.

2. Politikos nustatymas - daugiamečiai strateginiai planai. Ketverių metų planai (MASP - Multi-annual Strategic Plans) suformuojami kiekvienam prioritetui.

3. Igyvendinimas ir stebėsena - Europos kovos su nusikalstamumo grèsmèmis tarpdisciplininès platformos (EMPACT - European Multidisciplinary Platform against Criminal Threats). MASP yra igyvendinami per kasmetinius operatyvinius veiksmų planus (OAP Operational Action Plans), po vieną kiekvienam prioritetui.

4. Peržiūra ir įvertinimas. Vertinamas ciklo efektyvumas ir poveikis prioritetinèms grésmèms, igyta patirtimi naudojamasi rengiant kitą politikos ciklą.

SOCTA parengta išanalizavus daugiau kaip 2,3 tūkst. klausimynų, dešimtis tūkstančių kriminalinès žvalgybos kontribucijų ir pasitelkiant informaciją iš Europolo duomenų bazių. Svarbu, kad analizè atlikta pagal bendrą metodikąa ${ }^{24}$, kuri buvo peržiūrèta ir patvirtinta $2015 \mathrm{~m}$. Pagal ją vertinamos organizuotų nusikalstamų grupuočių charakteristikos, jų veiklos sritys, specifiniai geografiniai aspektai, analizuojama bendra organizuoto nusikalstamumo įtaka ir poveikis visuomenei. Naudodama kiekybine ir kokybine analize, SOCTA siekia nustatyti didžiausią grèsmę keliančias grupuotes ir jų veikimo sferas. Lietuvos policija, analizuodama nacionalines organizuoto nusikalstamumo grèsmes ir teikdama informaciją Europolui, taiko tą pačią metodiką. Lietuvos kriminalinès policijos biuras $2017 \mathrm{~m}$. parengè Sunkaus ir organizuoto

\footnotetext{
${ }^{22}$ Europos Komisija (2017), Komisijos ataskaita Europos Parlamentui, Europos vadovu tarybai ir tarybai, Briuselis: 2017-04-12, $\operatorname{COM(2017)~} 213$ final, p. 5.

${ }^{23}$ Politikos ciklas yra $2010 \mathrm{~m}$. patvirtinta sistema kovai su organizuotu nusikalstamumu. Ciklas trunka ketverius metus, jị igyvendinant optimizuojamas koordinavimas bei bendradarbiavimas pasirinktų prioritetų srityse.

${ }^{24}$ Council of The European Union (2015), Serious and Organised Crime Threat Assessment 2017 - Revised methodology, Brussels: 11-12-2015, 14913/15 LIMITE.
} 
nusikalstamumo nacionalinị grèsmių vertinimą (SONGV), kurio tikslas - atlikti nacionalinę strateginę sisteminę analizę, kuria remiantis formuoti pavojingiausių nusikalstamumo reiškinių prevencijos ir kontrolès politiką ${ }^{25}$.

SOCTA pripažista, kad organizuotas nusikalstamumas yra didelè grèsmè Europos Sąjungos saugumui, todèl kova su šiuo reiškiniu išlieka vienu iš pagrindinių prioritetų Europos saugumo darbotvarkeje. Lietuvos situacija, vertinant iš organizuoto nusikalstamumo kylančias grèsmes, atitinka Europos Sąungos požiūrị. Skirtumas tas, kad Europos Sąjungos kovos su organizuotu nusikalstamumu politikos ciklas labai aiškiai nubrěžia prioritetines kryptis, strateginius tikslus, jų igyvendinimo priemones ir veiksmingumo įvertinimą. Lietuvoje tokio nuoseklumo pasigendame: neaišku, keliems metams suformuota Strategija, strateginiai tikslai nepakankamai apibrèžti, tam tikrų priemonių igyvendinimas tik iš dalies aptariamas Vyriausybès programoje, na $\mathrm{o}$ apie ịvertinimą beveik nekalbama.

Analizuojant organizuotas nusikalstamas grupuotes ir jų struktūrą, svarbu apsibrèžti, apie kokio masto grupes kalbame. Europos Sąunga $2008 \mathrm{~m}$. susitarè dèl vienodo nusikalstamos grupuotès apibrèžimo ${ }^{26}$. Nusikalstama grupuote laikoma struktūrizuota organizacija, aktyvi ilgu ar apibrèžtu laikotarpiu, susidedanti iš daugiau kaip dviejų asmenų, kurie veikia kartu ir vykdo nusikaltimus, už kuriuos gresia daugiau kaip 4 metai laisvès atėmimo, siekian tiesioginès ar netiesiogines finansinès naudos ir veikia tarptautiniu lygmeniu ${ }^{27}$. Nors toks apibrěžimas ne visiškai atitinka Lietuvos Respublikos baudžiamajame kodekse nustatytą organizuotos grupés apibūdinimą, tai nedaro ịtakos renkant ir analizuojant kriminalinės žvalgybos informaciją, nes organizuoto nusikalstamumo grèsmių vertinimo uždavinys skiriasi nuo baudžiamojo persekiojimo tikslų: SOCTA esmé - įvertinti kriminalinès žvalgybos duomenis ir pateikti rekomendacijas nustatant nusikalstamumo grèsmes.

Organizuotas nusikalstamumas Europos Sąungoje apima labai daug veikų, kurios kasmet tampa vis labiau kompleksinès, o jų mastas auga. $\mathrm{Nu}$ sikalstamos grupuotės sugeneruoja milžiniškus pelnus, kurie kartais konkuruoja net su žinomomis tarptautinemis korporacijomis. Daugelis nusikalstamų grupuočių yra labai lanksčios, lengvai prisitaikančios prie besikeičiančios aplinkos, disponuojančios specialiomis ir techninèmis žiniomis bei patirtimi. Pačios pavojingiausios yra tos, kurios investuoja dideles lešas ị teisètą ekonomiką bei $\mathfrak{i}$ savo nusikalstamos veiklos tęstinumą ir plètimą. Vis labiau plinta

\footnotetext{
${ }^{25}$ Didžioji SONGV dalis yra riboto naudojimo, todèl šiame straipsnyje naudojama tik vieša informacija.

${ }^{26}$ Council of the European Union (2008), Council Framework Decision on the Fight against Organised Crime, Brussels: OJ L 300, 11-11-2008, p. 42.

${ }^{27}$ Čia pateiktas supaprastintas struktūrizuotas nusikalstamos grupuotès apibrěžimas.
} 
Crime-as-a-service (nusikaltimas kaip paslauga) reiškinys. Internetinė prekyba nelegaliais produktais ir paslaugomis leidžia individualiems nusikalteliams vykdyti savo nusikalstamą veiką be tradicinès organizuoto nusikalstamumo „infrastruktūros“. SOCTA duomenimis, šiuo metu Europos Sąjungoje veikia daugiau kaip 5 tūkst. tarptautinio masto organizuotų nusikalstamų grupuočių $^{28}$. Lietuvos kriminalinès policijos biuras Europolui pateikè informaciją apie mūsų šalyje veikiančias tarptautines grupuotes, atitinkančias visus anksčiau išvardytus kriterijus, tačiau tikslus skaičiaus neįvardijamas ${ }^{29}$. Pasak Lietuvos kriminalinès policijos biuro viršininko Rolando Kiškio, „Lietuvoje veikia keliasdešimt organizuotų nusikalstamų grupuočių, o didžiausia jų koncentracija yra Vilniuje, Kaune ir Šiauliuose ${ }^{\text {“30. }}$.

Toliau organizuotas nusikalstamumas nagrinejjamas pagal šias charakteristikas:

1. Organizuotų nusikalstamų grupuočiu tipai, struktūra, tarptautinè dimensija.

2. Organizuoto nusikalstamumo varantieji veiksniai ir „varikliai“.

3. Labiausiai pavojingos organizuoto nusikalstamumo veiklos sritys.

\subsection{Organizuotos nusikalstamos grupuotès}

SOCTA pateikia gana konkretų organizuotų nusikalstamų grupuočiu skaičių - daugiau negu 5 tūkst. Palyginimui, 2013 m. Europolas identifikavo 3,6 tūkst. grupuočių. Visgi šis ženklus padidejimas nebūtinai reiškia labai išaugusị organizuoto nusikalstamumo lygi. Autoriaus nuomone, tai labiau paveikta geresnio kriminalinès žvalgybos duomenų surinkimo ir išsamesnès analizès $^{31}$. Grupuočių struktūra, dydis, veiklos sferos yra labai ịvairios: 76 proc. (arba apie 3,8 tūkst.) nusikalstamų grupuočių susideda iš šešių ir daugiau narių $^{32}$. Apytiksliais skaičiavimais, Europos Sąjungoje gali veikti daugiau kaip 40 tūkst. organizuotų nusikaltèlių. Sunku pasakyti, daug tai ar mažai (Europos Sąjungoje gyvena $742 \mathrm{mln}$. piliečiu ), tačiau, kaip matysime vèliau, pasigilinus ị

\footnotetext{
${ }^{28}$ Europol (2017), SOCTA 2017, https:/www.europol.europa.eu/socta/2017/, 2017-12-02.

${ }^{29}$ Interviu su operatyviniu policijos darbuotoju, $2018 \mathrm{~m}$. kovo $17 \mathrm{~d}$.

${ }^{30}$ DELFI, Kriminalinès policijos biuro viršininkas: patys stebèjomès, kad dar gali būti tokiu nusikaltimu, 2017 m. spalio 27 d., https://www.delfi.lt/news/daily/lithuania/kriminalines-policijos-biuro-virsininkaspatys-stebejomes-kad-dar-gali-buti-tokiu-nusikaltimu.d?id=76185151, 2018-01-13.

${ }^{31} 2013 \mathrm{~m}$. buvo atliktas pirmas organizuoto nusikalstamumo grèsmių vertinimas pagal Europos Sąjungos kovos su organizuotu nusikalstamumu politikos ciklo koncepciją ir duomenų surinkimo bei analizės metodiką.

${ }^{32}$ Europol (2017), SOCTA 2017, https://www.europol.europa.eu/socta/2017/, 2017-12-02.
} 
šių 0,005 proc. gyventojų sugeneruojamą pelną, skaičiai neramina. Organizuotų nusikalstamų grupuočių nariai „atstovauja“ daugiau kaip 180 tautybių, kurių 60 proc. yra Europos Sąjungos piliečiai ${ }^{33}$. Septynios iš dešimties grupuočių veikia trijose ir daugiau šalių (10 proc. grupuočių yra aktyvios septyniose ir daugiau šalių $)^{34}$, kas atskleidžia tarptautinị organizuoto nusikalstamumo mastą bei didelị grupuočių mobilumą. Anksčiau grupuotès savo veiklą vykdè pagal tam tikrą specializaciją, pvz., vienos užsiemė plèšimais, kitos gabeno kokainą, trečios gamino sintetinius narkotikus. Šiuolaikiniame pasaulyje šios tendencijos sparčiai nyksta. Vis daugiau grupuočių (apie 45 proc.) užsiima vadinamaja polikriminaline veikla, joms neaktualu, kokị nusikaltimą atlikti, svarbiausia - gauti kuo didesni pelną. Tokio reiškinio plitimui labai pasitarnavo migracijos krizè. Didelis nelegalios žmonių kontrabandos paslaugų poreikis sudarè sąlygas organizuotam nusikalstamumui prisitaikyti ir persikvalifikuoti. Dalis grupuočių, anksčiau užsiiminèjusių kitais nusikaltimais, persimetè $\mathfrak{i}$ šią sritị, kuri yra labai pelninga ir nereikalauja didelès patirties.

Keičiasi ir grupuočių struktūrinè sudètis. Nors vis dar didžioji jų dalis veikia pagal hierarchinę struktūrą, daugèja horizontaliu pagrindu suformuotų grupių (apie 30-40 proc.), taip pat trumpam laikui suburtų susivienijimų, skirtų konkrečiam nusikaltimui atlikti, po to „išsivaikštančių“ (iki 20 proc.) $)^{35}$. Nusikalstamų grupuočių struktūra priklauso nuo vykdomų nusikaltimų pobūdžio. Pavyzdžiui, nelegalios migracijos organizatoriai yra ypač hierarchiški, nes tokiu būdu jie sugeba monopolizuoti ši nelegalų verslą, „suvalgydami“ mažesnius konkurentus. Didelès hierarchinès, su stipria struktūra grupuotès, turinčios iki šimto narių, kontroliuoja stambaus masto narkotikų biznị. Mafijos tipo grupuotès, ypač kinų, kolumbiečių, rusų ir italų, išskirtinai sudarytos iš vienos tautybės atstovų, visame pasaulyje gali turèti iki tūkstančio narių. Beveik visoje Europos Sąungos teritorijoje veikia neteisètos motociklininkų grupuotès (angl. Outlaw motor cycle gangs). Tai ypač stipriu hierarchiniu pagrindu suformuotos gaujos, turinčios aiškų lyderị - prezidentą, viceprezidentą, sekretorių, iždininką, seržantus, logistikos kapitonus ir kitus narius. Motociklininkų grupuotės dažniausiai užsiima prekyba narkotikais, turto prievartavimu, prekyba žmonėmis. Jų apraiškos matomos ir Lietuvoje. Su kibernetiniais nusikaltimais susiję nusikaltèliai, priešingai, nekuria struktūrizuotų grupuočių, o susiburia ad hoc pagrindu, kad ịvykdytų tam tikrus nusikaltimus (pvz., online prekyba ginklais ar narkotikais, sukčiavimas) arba suteiktų kitoms grupuo-

\footnotetext{
${ }^{33}$ Ten pat.

${ }^{34}$ Ten pat.

${ }^{35}$ Ten pat.
} 
tėms kokią nors paslaugą, reikalaujančią specifinių techninių ar mechaninių žinių. Tokie aukšto lygio specialistai gali vienu metu padeti keletui nusikalstamų grupuočių, joms nežinant, kad tie patys padejejjai dirba jų konkurentams. Dalis grupuočiu veikia „pagal pareikalavimą“, t. y. suaktyvejja tada, kai atsiranda naujų pasipelnymo galimybių, ir visai nesvarbu, kokio pobūdžio nusikaltimus reikès vykdyti.

Organizuotos nusikalstamos grupuotės turi daugybę savo pajamų srautų, todèl bent apytiksliai suskaičiuoti jų ịplaukas yra labai sunku. Jungtinių Tautų duomenimis, nusikalstamos veikos $2009 \mathrm{~m}$. pasaulyje sudare dviejų trilijonų eurų apyvartą ${ }^{36}$. Vien tik narkotikų biznis Europos Sajungoje sugeneruoja apie $24 \mathrm{mlrd}$. euru per metus ${ }^{37}$. Palyginimui, Lietuvos bendras vidaus produktas (BVP) $2016 \mathrm{~m}$. buvo apie $36 \mathrm{mlrd}$. eurų ${ }^{38}$. Europolo skaičiavimais, vidutinè grupuotė Europos Sąungoje, susidedanti iš 6-10 narių, per metus pasiekia apie 1,5 mln. euru pelno. Nelegalus pelnas varijuoja priklausomai nuo nusikalstamų veikų pobūdžio, tačiau grupuotès, užsiimančios tam tikro pobūdžio sukčiavimu, sugeba sugeneruoti milijardines pajamas.

Sparčiai vystantis technologijoms, organizuotos nusikalstamos grupuotès, siekdamos sutrukdyti tyrimams, imasi atsakomujų priemonių, nukreiptų prieš teisésaugos veiksmus. Tam reikia gerai išmanyti teisésaugos taikomus metodus, naudojamas priemones, taktiką ir technines galimybes. Svarbus veiksnys - geras skirtingų valstybių i̇statyminès bazès bei policijos bendradarbiavimo subtilybių žinojimas, kas ypač aktualu mobilioms („keliaujančioms“) grupuotems. Bendravimo tarp grupuočių narių apsaugai dažnai naudojami inovatyvūs komunikacijos būdai, tokie kaip šifruoti kanalai, palydovinio ryšio telefonai, užsienio valstybių SIM kortelès, koduota kalba, slengas, specialiai sukurtos telefonų programèlès ${ }^{39}$. Finansinès operacijos dažnai atliekamos užsléptais metodais - kriptovaliutų, alternatyvių bankinių paslaugų ar neformalių pinigu pervedimo sistemomis (pvz., Hawala, Hundi) ${ }^{40}$. Tokių atsakomųjų priemonių naudojimas yra glaudžiai susijęs su korupcija. Grupuotès bando

\footnotetext{
${ }^{36}$ United Nations Office on Drugs and Crime (2011), Estimating Illicit Financial Flows Resulting from Drug Trafficking and Other Transnational Organized Crime, https://www.unodc.org/documents/data-and-analysis/Studies/Illicit_financial_flows_2011_web.pdf, 2017-12-03.

${ }^{37}$ European Monitoring Centre for Drugs and Drug Addiction, Europol (2016), EU Drug Markets Report - In-depth Analysis, p. 23, http://www.emcdda.europa.eu/system/files/publications/2373/TD0216072ENN. PDF, 2017-12-03.

${ }^{38}$ Trading Economics (2017), Lithuania GDP, https://tradingeconomics.com/lithuania/gdp, 2017-12-03.

${ }^{39}$ Nusikalstama grupuotė naudojosi specialia išmaniųjų telefonų aplikacija, kuri leisdavo komunikuoti ịsijungus skrydžio režimą. Tokiu būdu teisèsauga negalèdavo nustatyti jų aktualios buvimo vietos.

${ }^{40}$ Hawala ar panašūs paslaugų teikejai - tai pinigų pervedimo sistemos, susijusios su specifiniais geografiniais regionais ar etninemis grupèmis, kurios atlieka pervedimus ir išgrynina lèšas. Paprastai lèšu perkèlimas nereikalauja fizinio ar elektroninio pinigų judejjimo.
} 
rasti ryšių operatyvinėse tarnybose, prokuratūroje, teismuose. Dažnai pasitelkiami teisininkai, finansininkai, inžinieriai.

Prieš dvidešimt ir daugiau metų organizuotas nusikalstamumas buvo neisivaizduojamas be smurto, kuris, siekiant ịbauginti, buvo demonstruojamas beveik atvirai - buvo gąsdinami verslininkai, deginami automobiliai ir pastatai. Šiuolaikiniai nusikalteliai, atvirkščiai, vengia smurto, nes jis patraukia teisèsaugos dèmeși, o nelegaliai „pelno siekiančioms“ organizacijoms tai visiškai nereikalinga.

Lietuvoje iš $2016 \mathrm{~m}$. vertintų organizuotų nusikalstamų grupuočių 30 proc. buvo labai aukšto, 28 proc. aukšto ir 40 proc. vidutinio pavojingumo lygio. Pagrindinė grupuočių koncentracija buvo Vilniaus ir Kauno apskrityse (čia 2016 m. registruota 51 proc. visų Lietuvos nusikalstamų veikų). Didžioji jų dalis turi hierarchinę struktūrą ir vykdo daugiau nei vienos krypties nusikaltimus. Apie 70 proc. grupuočių veikia nacionaliniu lygiu (veikla neapsiriboja vienoje apskrityje, jos turi ryšių su kitomis grupuotemis), o apie 30 proc. turi tarptautinès veiklos požymių ${ }^{41}$. Dažniausiai organizuotų nusikalstamų grupuočių nariai turi kriminalinių ryšių ar vykdo nusikaltimus Skandinavijos šalyse, Vokietijoje, Ispanijoje, Nyderlanduose ir Rusijoje.

\subsection{Organizuoto nusikalstamumo vystymosi veiksniai}

Nusikalstamumas technologijų amžiuje sparčiai tobulejja. Pagrindinis skatinantis veiksnys yra finansine nauda - nepriklausomai nuo to, ar ji bus gauta ịvykdžius vagystę ar kontrabanda ịvežus draudžiamas prekes. Nusikaltèliai gerai adaptuojasi prie geopolitinès situacijos, yra lankstūs, greitai keičia nusikaltimų padarymo būdus, pasinaudoja sukurtais organizuoto nusikalstamumo tinklais. Nusikalstamumas vystosi kartu su visuomene, koncentruojasi didžiausios gerovés teritorijose, nes jose lengviau daryti nusikaltimus. Matydami visuomenès poreikius ir kryptis, kuriose gali pasipelnyti, nusikaltèliai greitai pateikia ị rinką trūkstamas prekes ir paslaugas (tarp jų - ir draudžiamas). Pagrindiniai organizuoto nusikalstamumo „varikliai“ yra dokumentų klastojimas, pinigų plovimas ir prekyba internetu nelegaliomis prekemis bei paslaugomis. Šios grèsmès apima ir palengvina visas kitas organizuoto nusikalstamumo formas. Organizuoto nusikalstamumo verslo modeliai, apimantys ịvairiausias nusikalstamas veikas, dažnai priklauso nuo galimybės naudotis

\footnotetext{
${ }^{41}$ Lietuvos kriminalinès policijos biuras (2017), Sunkaus ir organizuoto nusikalstamumo nacionalinis grésmiu vertinimas, Vilnius, p. 19.
} 
padirbtais dokumentais ir nešvarių pinigų legalizavimo. Teisėsaugos įsikišimas suardant tokias schemas labai sumažina grupuočių potencialą, galimybes augti ir plèstis jų nelegaliam bizniui, skverbimąsi ị legalų verslą.

Pinigų išplovimas leidžia nusikalstamoms grupuotėms investuoti iš nelegalios veiklos ịgytas lèšas ị legalią ar nelegalią ekonomiką. Beveik visos nusikalstamos grupuotės yra priverstos plauti pinigus. Teisėsaugai sunku susekti nelegalius pinigų srautus, nes legalioje finansineje sistemoje vykdomi sandoriai būna užmaskuoti, jų beveik neįmanoma susieti su nusikaltimo vykdytojais ar nusikalstama veika. Pinigų plovimas tampa dideliu techniniu iššūkiu teisėsaugai, nes nusikaltèliai vis dažniau naudoja kriptovaliutas ir taiko anoniminius mokejjimo metodus. Atsirandančios naujos internetinès platformos ir netradicinès pinigų pervedimo sistemos dažnai būna nesureguliuotos i̊statymiškai, veikia pogrindyje arba „ant legalumo ribos“. Vykdoma ir grynųjų pinigų kontrabanda, ypač naudojant pašto siuntas. Smulkaus ir vidutinio masto pinigų plovimas pasireiškia lèšų investavimu į didesnès vertės prekes, nekilnojamajji turtą ar azartinius lošimus. Tam tikslui panaudojamos legalaus biznio struktūros, profesionalių buhalterių ir finansininkų paslaugos. Grupuotės, užsiimančios stambaus masto pinigų plovimu, pasitelkia sudetingas inovatyvias schemas. Jos plačiai išnaudoja bankines sistemas, atidarinėdamos naujas sąskaitas, kurdamos pervedimų grandines tarp priedanginių ir ofšorinių įmonių. Neapsieinama ir be korupcinių ryšių. Pačios stambiausios organizuotos nusikalstamos grupuotès naudojasi specializuotų pinigų plovimo sindikatų paslaugomis. Tokie sindikatai už 5-8 proc. mokestį, naudodamiesi sudètingomis pinigų plovimo grandinèmis, atlieka visą darbą legalizuodami milžiniškas iš nusikalstamų veikų sugeneruotas lèšas ${ }^{42}$. Europolo direktoriaus Robo Wainwrighto ${ }^{43}$ teigimu, Europolas nustate 400 profesionalių pinigų plovèjų, kurie nelegaliai uždirba milijardus legalizuodami per bankų sistemas iš narkotikų ir kitos nusikalstamos veiklos gaunamas lèšas ${ }^{44}$.

Dokumentų klastojimas tapo viena iš pagrindinių priemonių, padedančių vykdyti sunkius ir organizuotus nusikaltimus bei labai prisidedančių prie teroro atakų organizavimo. Šis reiškinys ypač paplito kaip migracijos krizės padarinys. Sukčiavimas pasireiškia pasinaudojant padirbtais arba autentiškais dokumentais, iggytais apgaulès būdu. Nusikalstamos grupuotès samdo aukš-

\footnotetext{
${ }^{42}$ Interviu su Europolo operatyviniu darbuotoju, $2018 \mathrm{~m}$. vasario $15 \mathrm{~d}$.

${ }^{43}$ Robas Wainwrightas ejo Europolo vykdomojo direktoriaus pareigas 2009-2018 metais. Nuo $2018 \mathrm{~m}$. gegužès $1 \mathrm{~d}$. šias pareigas perèmè Catherine De Bolle.

${ }^{44}$ Politico, Europe is losing the fight against dirty money, https://www.politico.eu/article/europe-moneylaundering-is-losing-the-fight-against-dirty-money-europol-crime-rob-wainwright/, $2018 \mathrm{~m}$. balandžio 2 d., 2018-04-08.
} 
tos kvalifikacijos specialistus, kurie sugeba pagaminti ypač geros kokybès ivvairios paskirties dokumentus. Dažniausiai klastojami asmens ar kelionès dokumentai (tapatybės kortelès, pasai, vizos, kvietimai atvykti ị Europos Sąjungą), kilmès dokumentai (gimimo, santuokos liudijimai), muitinès deklaracijos, sertifikatai, licencijos, blankai. Idiegus sudètingas asmens dokumentų apsaugos sistemas, grupuotems darosi sudètingiau pasigaminti aukštą kokybę atitinkančius dokumentus. Todèl jos vis dažniau stengiasi ịsigyti originalius dokumentus (perklijuodami nuotraukas ar manipuliuodami biografine informacija). Pastebėta, kad ypač išaugo pamestų ar pavogtų dokumentų skaičius. Lietuvoje per metus vidutiniškai pasigendama apie 10 proc. asmens tapatybès kortelių ir 5 proc. pasų (tai sudaro maždaug 37,5 tūkst. dingusių dokumentų kasmet $)^{45}$. Dalis šių pripažintų negaliojančiais dokumentų toliau sèkmingai naudojami vykdant nusikaltimus. Nestabili situacija ir kariniai konfliktai Europos Sąjungos pašonejje organizuotiems nusikaltèliams suteikia galimybę issigyti tuščių originalių blankų iš šių regionų, kuriais po to galima manipuliuoti ${ }^{46}$. Kitas reiškinys - išaugęs padirbtų gimimo liudijimų, santuokos sertifikatų ir darbo sutarčių skaičius. Neturint jokių kitų asmens dokumentų, siekiama legalizuotis su netikra tapatybe. Organizuotos nusikalstamos grupuotès išnaudoja legalaus verslo struktūras, pateikdamos falsifikuotas darbo sutartis vizai ar leidimui gyventi Europos Sąungoje. Tokių, ne taip gerai apsaugotų dokumentų klastojimas yra daug lengvesnis ir sunkiau kontroliuojamas.

Prekybai ir paslaugoms vis labiau persikeliant ị kibernetinę erdvę, išaugo ir nelegalus verslas online režimu. Toks reiškinys visiškai atspindi legalios ekonomikos ir prekybos vystymosi ypatumus. Kaip ir teisètas biznis, kur internetas labai pakeitè prekybos ịpročius ir vartotojų lūkesčius, kai neišèjus iš namų, per keletą dienų galima turèti naują prekę, atgabentą iš kito pasaulio krašto, taip ir nusikalstamumas prisitaikè prie naujos situacijos. Tikètina, kad ši sritis ateityje dar labiau tobulès ir plèsis, o ịvairios internetinès platformos taps pagrindiniu nelegalių prekių platinimo ịrankiu. Nelegalūs produktai ir paslaugos reklamuojamos ir platinamos tiek atvirajame, tiek „giliajame“ (angl. Darkweb) internete, priklausomai nuo pavojingumo ir galimų teisėsaugos sankcijų dydžio. Pavyzdžiui, narkotikai ar ginklai parduodami išskirtinai „giliajame“ internete, kuris vis labiau darosi decentralizuotas, tuo būdu dar sunkiau priei-

\footnotetext{
${ }^{45}$ Interviu su operatyviniu policijos darbuotoju, 2017 m. gruodžio 4 d.

${ }^{46}$ Sirijos konflikto pradžioje buvo galima nesunkiai ịsigyti tūkstančius originalių tuščių Sirijos asmens tapatybès dokumentų, kuriuos naudojant buvo vykdomos nelegalios migracijos operacijos bei radikalizavusių asmenų perkèlimas ị Europos Sąungą.
} 
namas teisèsaugai ${ }^{47}$. Priešingai, ịvairių „pusiau legalių“ naujų psichoaktyviųjų medžiagų, psichotropinių vaistų, anabolinių steroidų ar falsifikuotų drabužių galima įsigyti atvirajame internete. Gatvès prekyba narkotikais sparčiai eina ł online režimą. Taip pirkèjui sudaromos puikios sąlygos nesusitinkant „akis í akị su pardavejju bei gerokai sumažinant galimybę atkreipti pareigūnų dèmesį, įsigyti narkotikų. Kai kuriose JAV valstijose netgi sukurtos specialios išmaniujjų telefonų aplikacijos, per kurias galima užsisakyti marihuanos ir ji bus nedelsiant pristatyta i̇ nurodytą vietą, panašiai kaip picos išvežiojimo ar taksi užsakymo atvejais. Nelegalios prekybos apimties internete įvertinti ir sukontroliuoti praktiškai neịmanoma. Pirma, tai, ką teisèsauga pajègi pamatyti online, yra tik ledkalnio viršūnè, nes didelè dalis veiksmų atliekama "giliajame" internete; antra, tai vis dar nauja sritis tiek teisèsaugai, tiek politiką formuojančioms institucijoms; trečia, organizuotas nusikalstamumas tam skiria milžiniškus išteklius, kuo, deja, teisèsauga pasigirti negali. Nèra išsamių mokslinių tyrimų apie „giliojo“ interneto panaudojimo nusikaltimams vykdyti apimtį, tačiau kai kurios studijos teigia, kad aštuonios analizuotos „kriptorinkos“ „giliajame“ internete per mėnesį iš prekybos narkotikais sugeneruoja nuo 10,6 iki 18,7 mln. eurų pajamų (čia neįtraukti receptiniai vaistai, alkoholis ir tabakas) ${ }^{48}$.

Toliau bus nagrinejjami organizuoto nusikalstamumo varomieji veiksniai, kurie apima ne tik nusikalstamumą palengvinančius veiksnius, bet ir pažeidžiamumą visuomenèje, kas labai prisideda prie nusikalstamumo galimybių išplètimo. Juk nusikalstamumas vystosi kartu su visuomene. Svarbiausi veiksniai, suformuojantys nusikalstamumo pobūdị ir darantys ịtaką jo klestẻjimui, skatinantys vykdyti ịvairaus masto nusikaltimus, yra: technologinès inovacijos, geopolitinè situacija, transporto ir logistikos koncentracijos vietos, visuomenès požiūris, ịstatyminè bazè, konfliktai ir krizès Europos Sąjungos kaimynysteje.

Inovacijos komunikacijų, logistikos, finansų srityse suteikia galimybių vykdyti nusikaltimus anonimiškai bet kur ir bet kada, nedalyvaujant fiziškai, kaip iprasta, nusikaltimo vietose. Kadangi transporto ir logistikos infrastruktūra vis labiau pasitelkia online sistemas ir automatinị nuotolinị valdymą, organizuotos nusikalstamos grupuotès panaudoja šias sistemas manipuliuodamos gabenimo maršrutus, išnaudodamos tiekimo tinklus ir surinkdamos svarbią ir jautrią informaciją. Virtualios valiutos ir internetinès mokejimo platformos sudaro puikias sąlygas maskuoti nelegalius pinigu pervedimus neteisètai

\footnotetext{
${ }^{47}$ SOCTA-2017 duomenimis, net 57 proc. visų nelegalių produktų, siūlomų „giliajame“ internete, sudaro narkotikai.

${ }^{48}$ RAND Europe (2016), Internet-facilitated drugs trade - An analysis of the size, scope and the role of the Netherlands, https://www.rand.org/pubs/research_reports/RR1607.html, 2017-12-17.
} 
igytam turtui legalizuoti, tuo labai apsunkindamos teisėsaugos pareigūnų atsakomąsias priemones.

Sunkaus ir organizuoto nusikalstamumo situaciją Europos Sąjungoje labai veikia geopolitiniai veiksniai. Krizès Libijoje, Sirijoje ir Ukrainoje daro tiesiogini poveikị organizuotam nusikalstamumui Europoje. Kariniai konfliktai yra svarbiausias veiksnys migrantų krizės suklestejjimui, terorizmo ir radikalizacijos apraiškų padidejjimui ir ginklų kontrabandos suaktyvejjimui. Krizių apimtos valstybės tampa puikia užuovejja organizuotoms nusikalstamoms grupuotems koordinuoti savo veiksmus. Tarptautiniai susitarimai, tokie kaip vizų liberalizavimas, Šengeno sutartis ir laisvos prekybos sutartys, palengvina nelegalių prekių ar žmonių gabenimą. Laisvas asmenų judejjimas puikiai veikia organizuoto nusikalstamumo kontekste, sumažindamas galimybę būti išaiškintiems: nusikaltèliai gali judèti „be sienų“, vykdyti žaibiškus nusikaltimus skirtingose šalyse, apsigyventi bet kurioje valstybeje narëje. Teisėsaugos pareigūnams toks judejjimas vis dar yra labai suvaržytas. Pasitaiko situacijų, kai tam tikri veiksmai (pvz., naujos psichoaktyviosios medžiagos) vienoje šalyje yra draudžiami, o kitoje - ne. Organizuotas nusikalstamumas puikiai išnaudoja tokias įstatymų spragas ir neefektyvų teisėsaugos bendradarbiavimą, yra pajègus greitai prisitaikyti ar net numatyti būsimas ịstatymų pataisas. Asmeninè autoriaus patirtis atskleidè, kaip tarptautinè grupuoté, tiekusi psichoaktyviąsias medžiagas iš Kinijos, stebẻjo valstybių ịstatyminès bazės pokyčius. Kadangi ịstatymai vystèsi labai dinamiškai - kontroliuojamų medžiagų sąrašai buvo papildomi naujais preparatais, o transportavimas iš Kinijos užtrukdavo keletą ménesių, grupuotè turèjo gerai numatyti, ị kurią šalị saugu pristatyti prekes, o kur galbūt po keleto mènesių ta medžiaga bus nelegali, kelianti riziką jų „pusiau legaliam“ bizniui.

Organizuotas nusikalstamumas tam, kad paslèptų savo nusikalstamas veikas ir pelnus, plačiai išnaudoja transporto kompanijas ir importo-eksporto verslo struktūras. Nusikaltèliai dažnai patys steigia verslo įmones, per kurias vykdo nelegalią veiklą. Lygiai taip pat jie korupciniais principais samdo kompanijas nelegalioms operacijoms atlikti arba tiesiog ịsifiltruoja ị jas. Šioje vietoje tikslinga pakalbèti apie šešèlinę ekonomiką, kuri Lietuvoje, įvairiais vertinimais, siekia nuo 25 proc. ${ }^{49}$ iki 30 proc. ${ }^{50}$ ir yra didžiausia Europos Sąungoje kartu su Bulgarija ir Rumunija. Vienas iš organizuoto nusikalstamumo varomųjų veiksnių yra visuomenès požiūris ị tam tikrą problemą. Išplitusi sociali-

\footnotetext{
${ }^{49}$ Lietuvos laisvosios rinkos institutas (2016), Lietuvos šešèliné ekonomika, https://www.llri.lt/wp-content/ uploads/2016/12/LSE-2015-versija-internetui.pdf, 2018-01-14.
}

${ }^{50}$ Viešoji įstaiga „Lietuva be šešèlio” (2017), Statistika, http://www.beseselio.lt/statistika, 2018-01-14. 
nè tolerancija, rizikingo elgesio pateisinimas ar tiesiog per mažai informacijos gali sudaryti palankią aplinką tam tikriems nusikaltimams. Kontrabandinès cigaretès, nelegalus alkoholis ar degalai, padirbtos prabangos prekès yra tik keletas aukščiausio lygio socialinès tolerancijos pavyzdžių. Tokie veiksmai retai sulaukia neigiamo visuomenès požiūrio, ị juos žiūrima kaip ị "nekaltus nusikaltimus", keliančius nedidelę riziką vartotojui. Policijos duomenimis, net 62 proc. Lietuvos gyventojų toleruoja šešèlinę prekybą ${ }^{51}$. Bendrovès „Nielsen“ tuščiu pakelių tyrimo rezultatai atskleide, jog kontrabandinès cigaretès Lietuvoje užima 17,5 proc. rinkos ${ }^{52}$. Tam, kad visuomenè būtų išmokyta nepripažinti ir netoleruoti, nenaudoti kasdieniame gyvenime siūlomų kontrabandinių prekių, reikalingi šiuolaikiški interaktyvūs įrankiai, kurie parodytų gyventojams, kas vyksta, kaip su tuo kovojama ir ką žmogus asmeniškai gali padaryti, siekdamas, kad Lietuvoje gyventi būtų geriau.

Internetas ir technologinès inovacijos labai pakeitė geografinių aplinkybių ịtaką nusikalstamumui. Nusikaltèliai nebẻra suvaržyti teritorinėmis ribomis. Todèl šiandieniniame pasaulyje nusikalstamų grupuočių beveik nebeįmanoma susieti su kokiais nors specifiniais regionais ar nusikalstamumo centrais. Visgi kai kurios vietos išlieka svarbiais nusikalstamumo varomaisiais veiksniais. Pirmiausia, tai gerai išvystytos transporto ir komunikacijos infrastruktūros, naudojamos globaliam nelegalių produktų platinimui. Tokios padidinto aktyvumo vietos yra ten, kur yra didelis nelegalių prekių ar paslaugų poreikis, patogi geografinè padètis - artumas su kilmès ir paskirties šalimi, gera prieiga prie verslo ar investicijų; 75 proc. prekių tarp Europos Sąjungos ir kitų šalių pergabenama jūros transportu, apie $400 \mathrm{mln}$. keleivių per metus naudojasi Europos Sąungos vandens transportu ${ }^{53}$. Europoje yra daugybe išvystytų jūros uostų su puikia infrastruktūra ir didelemis galimybemis vystyti verslą. Nenuostabu, kad jie tampa tranzito zonomis nelegalioms prekèms ir svarbiais varomaisiais organizuoto nusikalstamumo veiksniais. Nusikalstamos grupuotès puikiai naudojasi silpnomis uostų kontrolès sistemų vietomis, falsifikuotomis deklaracijomis, ịrengtomis sléptuvemis legaliuose konteineriuose, klaidinančiomis plaukiojimo vèliavomis. Asmeninè autoriaus patirtis atskleidẻ unikalų faktą Antverpeno jūrų uoste, kai organizuota grupuotė manipuliavo informacija, ịsilauždama ị kontrolès sistemą ir pakeisdama konteinerio, kuriame buvo gabenamas didelis kiekis kokaino, duomenis tam, kad muitinès pareigūnai jo nesusektų. Nusikaltèliai taip pat išnaudoja išaugusị skrydžių

\footnotetext{
${ }^{51}$ Interviu su operatyviniu policijos darbuotoju, $2018 \mathrm{~m}$. kovo $17 \mathrm{~d}$.

${ }^{52}$ Baltic News Service, Kontrabandinès cigaretés Lietuvoje užima 17,5 proc. rinkos - tyrimas, 2018 m. sausio 11 d., http://www.bns.lt/topic/1912/news/51691229/, 2018-01-21.

${ }^{53}$ Europol (2017), SOCTA 2017, https://www.europol.europa.eu/socta/2017/, 2018-01-14.
} 
skaičiu, nedidelius oro uostus su silpnesne patikrų sistema, mažų kainų oro bendroves. Vis dažniau kontrabanda gabenama naudojantis siuntinių ir pašto paslaugomis. Sukontroliuoti ir aptikti nelegalias prekes milžiniškame siuntų sraute, taikant ịprastus metodus, yra beveik neįmanoma. Pasitaiko atvejų, kai nusikaltèliai patys įsteigia siuntinių ekspedicijos bendroves, kurios be jokios rizikos gabena kontrabandines prekes.

\subsection{Organizuoto nusikalstamumo veiklos sritys}

Vertinant kriminogeninę situaciją Lietuvoje, 2014-2016 metais nusikaltimų mažèjo, tačiau $2017 \mathrm{~m}$. užregistruotų nusikalstamų veikų skaičius gerokai šoktelèjo, lyginant su 2016 m., jų padaugèjo 5 tūkst., iki 61 tūkst. ${ }^{54}$ Sunkių ir labai sunkių nusikaltimų kriminogeninis fonas nuo 2014 metų išlaiko stabilią mažèjimo tendenciją (2017 m. užregistruota 2,1 tūkst. tokio pobūdžio nusikaltimų). 2016-2017 metais pasižymejjo su narkotikais siejamų tyrimų dominavimas, antrą ir trečią poziciją užėmé plešimai ir sukčiavimai, taip pat stebimas ypač brutalių nužudymų padidejjimas, todèl manytina, kad bendra kriminogeninès būklès situacija dominuojančio nusikalstamumo srityje išlieka kelianti grèsmę ir reikalaujanti nuolatinio politinio ir darbinio dèmesio. Toliau apžvelgiami kovos su organizuotu nusikalstamumu prioritetai Europos Sąungoje 2018-2021 metams. Europos Sąjungos Tarybos išvados nustate dešimt prioritetinių kovos su sunkiais ir organizuotais nusikaltimais krypčių ${ }^{55}$ :

1. Kibernetiniai nusikaltimai. Tai globalus fenomenas, tokie nusikaltimai yra „be sienu“", kaip ir pats internetas. Visuomenè kaip niekada yra skaitmenizuota, o nusikaltèliai išmoko technologines naujoves pritaikyti naujiems nusikalstamo verslo modeliams. Kasmet pasaulyje dèl kibernetinių išpuolių prarandama $400 \mathrm{mlrd}$. eurų ${ }^{56}, 2017 \mathrm{~m}$. buvo pasikėsinta i̇ 2 mlrd. privačių duomenų įrašų ${ }^{57}$. Didžiausią grèsmę kelia išpuoliai prieš informacines sistemas, sukčiavimas negrynosiomis mokejjimo priemonèmis ir prievartos prieš vaikus turinio platini-

\footnotetext{
${ }^{54}$ Čia ir vèliau remiamasi Informatikos ir ryšių departamento prie Vidaus reikalų ministerijos nusikalstamumo ir ikiteisminių tyrimų statistika, https://www.ird.lt/lt/paslaugos/nusikalstamu-veikuzinybinio-registro-nvzr-paslaugos, 2018-01-21.

${ }^{55}$ Council of the European Union (2017), Council conclusions on setting the EU's priorities for the fight against organised and serious international crime between 2018 and 2021, http://data.consilium.europa.eu/ doc/document/ST-9450-2017-INIT/en/pdf, 2018-03-05.

${ }^{56}$ Europos vadovų taryba (2017), ES kova su organizuotu nusikalstamumu, http://www.european-council. europa.eu/lt/policies/eu-fight-against-organised-crime-2018-2021/, 2018-03-10.

${ }^{57}$ Europol (2017), Internet Organised Crime Threat Assessment, p.10.
} 
mas. Pažymėtina, kad Lietuvos nusikalstamos grupuotės yra aktyvios mokejjimo kortelių sukčiavimo srityje. Tikètina, kad kibernetinių nusikaltimų grèsmés bus aktualios ir ateityje.

2. Narkotikai. Nelegali narkotikų prekyba išlieka didžiausia nusikalstama sfera: 45 proc. nusikalstamų grupuočių Europos Sąjungoje užsiima narkotiku gamyba ir platinimu ${ }^{58}$. Ši veikla sugeneruoja milžiniškus pelnus, kurie vèliau finansuoja kitas nusikalstamas veikas. Pramoninio masto sintetinių narkotikų gamyba Europos Sąjungoje paverte šį regioną pagrindiniu šaltiniu, aprūpinančiu tokiomis medžiagomis visą pasaulị. Nusikalteliai investuoja $\mathfrak{i}$ naujas technologijas, kad tomis pačiomis sąnaudomis gautų didesnę narkotikų išeigą, o kartu ir pelną. Europolas fiksavo Lietuvos organizuotų nusikalstamų grupuočių suaktyvèjimą heroino ir sintetinių narkotikų apyvartos srityse. Narkotikų gamyba, gabenimas ir prekyba išliks pagrindine grèsme ir ateityje.

3. Nelegali migracija. Beprecedentiškai išaugę migracijos srautai pavertė nelegalią migraciją viena pelningiausių ir labiausiai paplitusių organizuoto nusikalstamumo sričių, kurią galima lyginti su narkotikų prekyba. Baiminamasi, jog migracijos krize gali tapti rimtu ịvairių formų žmonių išnaudojimo katalizatoriumi. Didelès migrantų grupès tampa potencialiomis aukomis, pažeidžiamomis dèl nelegalaus buvimo Europos Sajungoje. Kad pasiektų Europą 90 proc. migrantų moka prekiautojams žmonėmis. Nors $2014 \mathrm{~m}$. kilusią migracijos problemą bendromis šalių pastangomis pavyko suvaldyti, jos mastas $2017 \mathrm{~m}$. gerokai sumažèjo, prognozuotina, kad dèl karinių konfliktų ir skurdo tam tikruose regionuose ši sritis ir toliau bus patraukli organizuotam nusikalstamumui, todèl išliks didele grèsme.

4. Organizuoti turtiniai nusikaltimai. Kurị laiką šie nusikaltimai buvo primiršti, netraktuoti kaip grèsmė. Pastaruoju metu jų daugèja, ypač vykdomų mobilių grupuočių, veikiančių visoje Europos Sąungos teritorijoje. Besinaudojančios sekimo kertant sieną priemonių sąveikumo spragomis, tokios grupuotès vykdo plěšimus, įsilaužimus ir automobiliu vagystes. Išvystyta internetinè prekyba palengvino galimybes parduoti vogtas prekes. Lietuvos nusikalstamos grupuotès stebimos kaip vienos iš aktyviausių. Reikia pripažinti, kad nepaisant didelio mobilụ grupuočių aktyvumo, tokio pobūdžio nusikaltimų tyrimai daugelyje šalių nèra prioritetiniai, $\mathfrak{x}$ juos nežiūrima kaip ị sunkias veikas.

5. Prekyba žmonèmis. Skirtingas šaliu ekonominis išsivystymas tapo pagrindine prekybos žmonėmis varomaja jèga. Visų formų preky-

${ }^{58}$ Europol (2017), SOCTA 2017, https://www.europol.europa.eu/socta/2017/, 2018-01-14. 
bos žmonėmis metinis pelnas visame pasaulyje yra 29,4 mlrd. eurų ${ }^{59}$. Organizuotos nusikalstamos grupuotès taikosi ił labiau pažeidžiamus žmones ne tik seksualinių paslaugų sferoje, bet sparčiai didèja vergovès reiškinys, kuris labai prisideda prie šešèlinès ekonomikos augimo, mažina dirbančiųjų algas ir lètina ekonomikos augimą. Išnaudojimas darbo tikslais $2017 \mathrm{~m}$. apèmé 58 tautybių aukas ${ }^{60}$. Akivaizdu, kad aukų daug daugiau, nei rodo oficialūs duomenys, todèl viena iš didžiausių teisėsaugos problemų išlieka aukų identifikavimas ir apsauga.

6. Sukčiavimas. Sukčiavimas finansų srityje atima iš valstybiu narių ir iš pačios Europos Sajungos milžiniškas pajamas, kurios galètų būti investuojamos ì infrastruktūrinius projektus, regionų vystymą: „kasmet nusikalstamos grupès, pasinaudojusios tuo, kaip PVM tvarkomas vykdant tarpvalstybinius sandorius, pavagia $60 \mathrm{mlrd}$. eurų "61. Didžiausių nuostolių atneša sukčiavimas akcizinių prekių srityje (šešèlinè tabako gaminių industrija, alkoholio ir degalų kontrabanda) ir dingusio prekiautojo Bendrijos viduje sukčiavimo schema (MTIC, angl. Missing Trader Intra-Comminity). Akcizų sukčiavimo atvejais, be kitų grupuočių, aktyviai veikia ir Lietuvos nusikaltèliai.

7. Ginklu prekyba. Nelegali prekyba ginklais labai padidina teroristinių išpuolių riziką, todèl ši sritis pastaraisiais metais yra ypač svarbi. Nesenos džihadistų atakos Europos Sąjungoje buvo ịvykdytos naudojant nelegalius ginklus. Ginklų vis lengviau galima ịsigyti internetu, kas dar labiau apsunkina teisésaugos institucijų intervencijas. Be organizuotų grupuočių, stebimas išaugęs pavienių asmenų aktyvumas. Didejjantis ginkluotų susiremimų tarp nusikalstamų grupuočių skaičius, kuriuose neretai nukenčia su tuo nesusiję pašaliniai asmenys, tik patvirtina ginklų prekybos, kaip didelio pavojaus veiksnị Europos Sąungai.

8. Nusikaltimai aplinkai. Tokie nusikaltimai tapo viena pelningiausiu nusikalstamų organizacijų veiklų pasaulyje. Jie kenkia ne tik aplinkai, bet ir visuomenei, ir visai ekonomikai. Didžiausių problemų sukelia nusikalstamos organizacijos, užsiimančios neteisèta prekyba laukiniais augalais ir gyvūnais bei nelegalia veikla su atliekomis. Korupciniai ryšiai su vietos valdžios ir legalaus verslo struktūromis labai prisideda prie sèkmingo tokių veikų pletojimo (manipuliavimas savivaldybių konkursuose ar viešuosiuose pirkimuose dèl atliekų tvarkymo). Tai nauja prioritetiné

\footnotetext{
${ }^{59}$ Europos Komisija (2017), Komisijos komunikatas Europos Parlamentui ir Tarybai: Prekybos žmonèmis panaikinimo ES strategijos igyvendinimo ataskaita ir konkretūs tolesni veiksmai, Briuselis: 2017-12-04, $\operatorname{COM}(2017) 728$ final.

${ }^{60}$ E. Forte, T. Schotte, S. Strupp (2017), „Serious and Organised Crime in the EU: The EU Serious and Organised Crime Threat Assessment (SOCTA) 2017i", European Police Science and Research Bulletin 16, p. $13-26$.

${ }^{61}$ Europos vadovų taryba (2017), ES kova su organizuotu nusikalstamumu, http://www.european-council. europa.eu/lt/policies/eu-fight-against-organised-crime-2018-2021/, 2018-03-11.
} 
sritis, reikalaujanti didesnio teisèsaugos indèlio ir glaudesnio šalių bendradarbiavimo.

9. Finansiniai nusikaltimai. Svarbiausias nusikaltèlių tikslas yra pelnas, o inovacijos finansinių paslaugų srityje, pavyzdžiui, virtualiosios valiutos ir anoniminès išankstinio mokejjimo kortelès, suteikè naujų galimybių užsiimantiems finansiniais nusikaltimais. Europolo duomenimis, 0,71,2 proc. bendro Europos Sąungos BVP galima priskirti prie abejotinos finansinès veiklos, ittartini metiniai finansiniai srautai sudaro daugiau kaip 29 mlrd. eurų, o daugiau negu 4 mlrd. eurų nusikalstamu būdu igytų lèšu yra išplaunama pasinaudojant virtualiosiomis valiutomis ${ }^{62}$. Pagrindinis teisèsaugos institucijų siekis yra konfiskuoti lèšas, atskleisti grupuotes, teikiančias pinigu plovimo paslaugas. Ši sritis traktuojama kaip vienas iš nusikalstamumo „variklių“, todèl negali būti tiriama atskirai nuo kitų organizuoto nusikalstamumo sričių.

10. Dokumentu klastojimas. Kelionès dokumentų saugumas yra svarbus kovojant su terorizmu ir organizuotu nusikalstamumu ir prisideda prie geresnès sienų apsaugos ir migracijos valdymo. Europos Sąjunga siekia kovoti su nusikalstamomis organizacijomis, klastojančiomis dokumentus ir jais aprūpinančiomis kitus nusikaltèlius. Manytina, kad toks sukčiavimo būdas taps vienu iš sparčiausiai besivystančių nusikalstamumo „rinkų“, todèl jis turi būti traktuojamas kaip viena iš didžiausių grèsmių. Kaip jau buvo minèta, ši nusikalstamumo sritis yra horizontali, palengvinanti kitas organizuoto nusikalstamumo veikas.

Apibendrinant organizuoto nusikalstamumo keliamas grèsmes, darytina išvada, kad esama pakankamai išsamios informacijos, leidžiančios susidaryti objektyvų vaizdą apie šio reiškinio mastą, finansinę apyvartą, grupuočių struktūrą, veiklos sritis, poveikį ekonomikai ir viešajam saugumui. Konkrečiai Ł̇vardijami ir didžiausią grèsmę Europos Sąjungai keliantys nusikaltimai, didžioji jų dalis taip pat aktualūs Lietuvai. Pagrindinis iššūkis atsakingoms institucijoms ir visai visuomenei - duoti tinkamą atsaką, kuris galètų efektyviai prisidèti prie šios grèsmès mažinimo.

\section{Organizuotas nusikalstamumas ir terorizmas}

Vertinant organizuotą nusikalstamumą, stebima, kad jis dažnai persipina su kitomis grèsmèmis. Šiame straipsnyje analizuoti organizuoto nusikalstamumo ryšiai su korupcija, kibernetiniais nusikaltimais, migracijos krize,

${ }^{62}$ Interviu su Europolo operatyviniu darbuotoju, 2018 m. vasario 15 d. 
nestabilumu Europos Sąungos kaimynysteje. Lietuvoje plačiai diskutuojama ir apie hibridines grèsmes. Vienas iš galimų hibridinių grèsmių įrankių yra organizuotas nusikalstamumas ir nevaldomi migracijos srautai. Britų žurnalistas ir saugumo politikos ekspertas Edvardas Lucas išskiria dvidešimt Kremliaus "toksinių taktikų“, tarp kurių figūruoja korupcijos panaudojimas, kibernetinès atakos ir organizuoto nusikalstamumo tinklai, siekiantys paveikti sprendimų prièmejus ir visuomenès nuomonę ${ }^{63}$.

Verta plačiau išnagrinèti organizuoto nusikalstamumo sąsajas su terorizmu. Toks santykis pasireiškia per ginklų kontrabandą, finansavimą, dokumentų klastojimą ir radikalizacijos procesus, ypač ịkalinimo ịstaigose. Be to, tiek organizuotos, tiek teroristinès grupuotès naudoja tuos pačius gabenimo kelius (pvz., Balkanų), todèl savo tikslams pasitelkia tas pačias logistikos ir infrastruktūros sistemas. Tokie nusikaltimai kaip dokumentų klastojimas ir ginklų kontrabanda labai palengvina pasirengimą teroristinèms atakoms ir jų vykdymą. Išpuolị Berlyne Kalèdų mugès metu 2016 m., kurio metu žuvo 12 žmonių, ịvykdè pabėgèlis iš Tuniso, kuris, atmetus jo prieglobsčio prašymą, sèkmingai keliavo po visą Europą naudodamasis ịvairiais dokumentais su skirtingomis tapatybėmis. Teroro aktų Paryžiuje ir Briuselyje 2015-2016 m. tyrimas atskleide kai kurių itariamųjų ryšius su organizuotu nusikalstamumu ${ }^{64}$. Teroristinès organizacijos siekia kaupti nusikalstamu būdu gautas lèšas, kuriomis po to finansuoja terorizmo veiklą. Pinigų plovimu užsiimantys sindikatai sèkmingai teikia paslaugas tiek organizuotoms nusikalstamoms grupuotėms, tiek teroristinèms organizacijoms. Nenuostabu, kad teroristai pasinaudojo migracijos krize ir organizuotų grupuočių pagalba perkèlè dalį savo patikètinių i Europą.

Organizuoto nusikalstamumo ir terorizmo grèsmė yra dvejopa. Pirma, organizuoto nusikalstamumo infrastruktūros panaudojimas (ịsigyjant ginklus ar dokumentus bei gabenant žmones) gali atvesti prie ypač pavojingų mirtinų ginklų ịsigijimo teroristiniams tikslams. Antra, teroristų ịsitraukimas ị organizuotą nusikalstamumą jiems leidžia sugeneruoti apčiuopiamus pelnus, kurie bus panaudoti su terorizmu susijusiems veiksmams. Nors tik 5,5 proc. Europolui žinomų su terorizmu susijusių asmenų yra turèję ryšių su organizuotu nusikalstamumu ${ }^{65}$, toks reiškinys, ypač žvelgiant per radikalëjimo procesus, vis labiau kelia nerimą. Kalèjimai dažnai tampa ịtraukimo ị terorizmą vietomis. Žinant šiuolaikinių nusikaltelių lankstumą ir greitą prisitaikymą prie naujų situacijų, ši tema ateityje bus dar labiau aktualesnè. Būtent ryšys su teroriz-

\footnotetext{
${ }^{63}$ Edward Lucas (2017), „The Kremlin's 20 toxic tactics”, https://www.stopfake.org/en/edward-lucas-thekremlin-s-20-toxic-tactics/, 2018-03-18.

${ }^{64}$ Europol (2017), SOCTA 2017, https://www.europol.europa.eu/socta/2017/, 2018-03-18.

${ }^{65}$ Interviu su Europolo operatyviniu darbuotoju, $2018 \mathrm{~m}$. vasario $15 \mathrm{~d}$.
} 
mu yra vienas iš svarbiausių požymių, rodančių, kad organizuotas nusikalstamumas nèra šiaip visuomenei žalinga veikla. Jis turi būti traktuojamas kaip reiškinys, keliantis grèsmę nacionaliniam saugumui. Nors Lietuvoje neturime daug pavyzdžių, siejančių organizuoto nusikalstamumo ir terorizmo grèsmes, tačiau viešai žinomas ịvykis, kai prieš maždaug dešimtmetị Lietuvos nusikalstamo pasaulio atstovai sieke tiekti ginklus ir sprogmenis Airijos teroristinei grupei The Real Irish Republican Army (RIRA) ${ }^{66}$, puikiai iliustruoja tokias galimybes ir skatina žvalgybos bei operatyvines tarnybas panašius reiškinius traktuoti kaip ypač svarbius.

Nepervertinant didejjančių tarpusavio ryšių, verta pastebèti, kad organizuotas nusikalstamumas ir terorizmas vis tik siekia skirtingų tikslų. Aiški organizuoto nusikalstamumo pelno siekimo natūra daugeliu atvejų nesuderinama su terorizmu, kuris paremtas religiniais įsitikinimais ir siekia kuo daugiau aukų. Organizuotas nusikalstamumas jokiu būdu nenori sunaikinti klestinčios Vakarų visuomenès, iš kurios kasdien pelnosi. Kitas dalykas - šiuolaikiniai organizuoti nusikaltèliai siekia išlikti nepastebèti, vengia bet kokio dèmesio; teroristai, priešingai, siekia atkreipti kuo didesnị žiniasklaidos ir teisėsaugos dèmesį, nori būti girdimi ir matomi. Visgi nepaisant kol kas sąlyginai ribotų organizuoto nusikalstamumo ir terorizmo sąsajų, tokie reiškiniai privalo būti akylai stebimi ir analizuojami teisèsaugos ir saugumo agentūrų.

\section{Išvados}

Išanalizavus situaciją Lietuvoje ir Europos Sąungoje, nekyla abejonių, kad organizuotas nusikalstamumas nèra tiesiog standartinè problema. Stebint tarptautinio organizuoto nusikalstamumo skverbimąsi ị legalų verslą, iš nusikalstamų veikų sugeneruojamo pelno mastus, daromą ịtaką šalių ekonomikoms ir visuomenès raidai, sąsajas su kitomis grèsmėmis (nelegalia migracija, korupcija, kibernetinèmis atakomis, terorizmu), atsižvelgiant ị vis didejančius hibridinius pavojus, yra akivaizdu, kad jis kelia didžiulę ir vis didejjančią grèsmę nacionaliniam ir tarptautiniam saugumui. Tai neigiamai veikia visuomenès saugumą, visuomenès sveikatą, demokratines institucijas ir ekonominį stabilumą visame pasaulyje. Organizuotas nusikalstamumas kaip reiškinys vystosi lygiai taip pat, kaip ir visuomenè, darosi vis labiau lankstesnis ir dinamiškesnis, igauna naujas formas. Todèl šios problemos ịprastomis priemonėmis išspręsti

\footnotetext{
${ }^{66}$ Lietuvos apeliacinis teismas (2017), Byla 1A-4-398/2017, http://eteismai.lt/byla/252918950797792/ 1A-4-398/2017, 2018-04-09.
} 
nę̇manoma, atsakas grèsmei privalo būti inovatyvus. Pagrindinis klausimas: ar mūsų visuomenẻ pasirengusi netoleruoti visų rūšių nusikalstamumo, ar mes galime tapti atsparūs šiai grèsmei?

Lietuvoje organizuotas nusikalstamumas daugiau kaip penkiolika metų ìvardijamas kaip grèsmè nacionaliniam saugumui. Galima teigti, kad turime gerą ịstatyminę bazę, aiškią politinę valią ir visuomenès lūkesčius. Operatyvinès tarnybos disponuoja pakankamai išsamia ir patikima informacija apie organizuotas nusikalstamas grupuotes, jų narius ir veiklą. Vis dèlto reikia pripažinti, kad, nors Europos Sąjungos kovos su organizuotu nusikalstamumu politikos lygmeniu badoma suintensyvinti valstybių narių atsaką i šią problemą, Lietuvoje kol kas nesiimama jokių ypatingų priemonių, ši grèsmẻ yra iš esmès inertiškai ịvardijama tarp svarbiausių pavojų, o jos sprendimo būdai apsiriboja bendrinėmis standartinėmis priemonèmis (bendradarbiavimo stiprini$\mathrm{mu}$, veiksmų koordinavimu, nusikaltimų išaiškinimu). Siūlytina ateityje rengiant nacionalinio saugumo vertinimą, Strategijoje aiškiau apibrèžti grèsmes ir kovos prioritetus. Autoriaus nuomone, didžiausias dèmesys kovojant su šiuolaikiniu nusikalstamumu turètų būti kreipiamas ị:

- Keitimąsi informacija nacionaliniu ir tarptautiniu lygiu, ypač užtikrinant sklandų teisésaugos ir žvalgybos institucijų bendradarbiavimą.

- Koncentraciją i didžiausias grèsmes keliančius nusikaltimus ir nustatytus Europos Sąjungos kovos prioritetus. Tam būtina skirti pakankamai išteklių, vykdyti igyvendinimo stebėseną ir vertinimą.

- Sąsajas tarp organizuoto nusikalstamumo ir kitų grèsmių, ypač terorizmo nuolatinį stebejjimą ir greitą reagavimą.

- Neigiamo visuomenès požiūrio i̇ vadinamuosius „nekaltus nusikaltimus" formavimą, socialinès tolerancijos mažinimą, kovą su šešèline ekonomika ir korupcija.

- Istatymų sistemos harmonizavimą Europos Sąjungos lygmeniu, siekiant išvengti „pusiau legalių“ verslo formų, suvienodinant riziką organizuotam nusikalstamumui veikti visoje Europos Sajungos teritorijoje.

Organizuotas nusikalstamumas neturi sienų, jis seniai tapo tarptautiniu, o šalys vis dar bando kovoti su šiuo reiškiniu remdamosios nacionaliniais sprendimais. Dèl šios priežasties esama sistema yra gana nelanksti, trukdo sklandžiai dalintis informacija, ypač užkardant finansines nusikalstamų grupuočių schemas. Visos Europos Sąjungos valstybės narès turi finansinių tyrimų institucijas (Lietuvoje - Finansinių nusikaltimų tyrimo tarnyba), kurių pagrindiniai uždaviniai yra analizuoti ịtartinus sandorius, užkirsti kelią pinigu plovimui ir terorizmo finansavimui. Nacionaliniu lygiu šios tarnybos puikiai 
atlieka savo darbą, tačiau tarpusavyje jos reguliariai nebendradarbiauja, neturi bendros duomenų bazès. Europolo atlikta studija parodè, kad 2014 m. finansinių tyrimų tarnybos gavo beveik $1 \mathrm{mln}$. pranešimų apie įtartinus sandorius, o net 65 proc. jų buvo atlikti vos dviejose Bendrijos šalyse - Jungtineje Karalystejje ir Nyderlanduose ${ }^{67}$. Dar viena spraga - Europos Sąungos nesugebejjimas kartu atremti kibernetines grésmes. Kaip ir pinigų plovimo atveju, valstybės narès dažniausiai veikia pavieniui. Europos bendruomene privalo iš esmès pakeisti mąstymą ir užtikrinti koordinuotą ir greitą reagavimą ì grèsmes. Tarptautinis organizuotas nusikalstamumas negali būti ịveiktas vienos tarnybos ar net vienos šalies pastangomis. Sèkmè labai priklauso nuo teisèsaugos institucijų galimybès suburti globalų ekspertų tinklą, užtikrinti patikimas kriminalinès analizès galimybes ir garantuoti finansavimą bei aprūpinimą ištekliais.

2018 m. kovas

\footnotetext{
${ }^{67}$ Politico, Europe is losing the fight against dirty money, 2 April 2018, https://www.politico.eu/article/ europe-money-laundering-is-losing-the-fight-against-dirty-money-europol-crime-rob-wainwright/, 2018-04-10.
} 